\title{
Evaluation of Climate Change Impact And Groundwater Vulnerability Assessment In Rangpur District, Bangladesh
}

\author{
Dr. Md. Emdadul Haque ${ }^{1}$ and Anjum Tasnuva ${ }^{2}$ \\ ${ }^{12}$ Assistant Professor, Department of Disaster Management, Begum Rokeya University, Rangpur
}

\begin{abstract}
Groundwater vulnerability assessment was carried out in Rangpur district due to climate change and with an aim to assess the climatic change evaluation and groundwater vulnerability. The climatic parameter such as rainfall and temperature were used to evaluate the changes of climate. Moisture index, drought hazard index, flood hazard index and groundwater vulnerability assessment were calculated following the Thornthwaite model (1948), Shahid and Behrawan (2008) and GIS based DRASTIC model. The analysis reveals that rainfall related flood hazards may increase over the years as the duration and magnitude of rainfall may increase. As temperature of Rangpur may change, so potential evaporation will change. Risk ranking revel that severity and frequency rainfall flood is higher than meteorological drought and the highest flood risk indicate moderate-to-high flood risk condition. The highest meteorological drought risk indicates drought risk condition sufficiently high. Groundwater level is declining at an alarming rate which causing the groundwater moderate vulnerable to high vulnerable condition.
\end{abstract}

Keywords: Vulnerability, Hazard, DRASTIC, GIS and Meteorological drought.

\section{Introduction}

Rangpur division is located at the foot of the Himalaya in the northern part of Bangladesh which is one of the natural disaster prone areas than any other parts of the country. This is because of its geographic location (close to the Himalayan), high population density, high levels of poverty (include Monga affected area), reliance of livelihoods on climate sensitive sectors particularly agriculture where agriculture dependent population is $74.20 \%$ (Banglapedia, 2003), etc. Recent climate variability and change seems to have adversely affected floods and droughts hazards in several areas of Rangpur division and this tendency may likely to continue. Therefore, there is need to study the climate scenarios, variability and the impact of change on hydrometeorological hazards and vulnerability and assessing future risk. A number of climatic parameters and anthropogenic stress influence to ambient environmental condition. In addition, the statistical variation of natural weather is significantly attributed to environmental hazards. The environmental hazards may lead to devastating consequences while it is appeared as disaster (flood, drought, river bank erosion and poverty). The long term suffering due to environmental hazards directly make a linkage between resilience pattern and vulnerability in the community.

The regional impacts on climate would be change in rainfall pattern on a warmer climate and its may increase $5-6 \%$ rainfall by 2030 owing to more intense monsoon and ice melting which will create frequent, big and prolonged flood as well as increased drought outside the monsoon season (IPCC, 2008). According to ADB (1994) reported that the lower precipitation in dry season has been increased drought risk in Bangladesh. The drought hazards mostly affected from (March-May) in the pre monsoon and post monsoon (October-November). In the last fifty years, around 19 drought events have been suffered in the country. The significant years of 1973, 1978, 1979, 1981, 1982, 1992, 1994, 1995, 2000, 2006 are worth mentioning. The ground water level has been depleted ranged from 8.95 to $18.5 \mathrm{~m}$ due to over extraction in purpose of drinking, irrigation and household at the northern region of Bangladesh. The climatic and non-climatic effect is coincided with climatic stress to water scarcity for irrigation and household purpose. It is negatively correlated with ambient climatic condition and irrigation activities.

The northern part of the country (Rangpur district) is suffered from drought hazards while it is increased based on seasonal variation. The agricultural activities and crop production rate incorporated with water availability and seasonal climatic condition. Drought hazards and its negative impact on socioeconomic condition influence the seasonal poverty (Monga) at the study area. In addition, the environmental hazards and seasonal poverty act as a limiting factor for the socio-economical development.

\subsection{Objectives}

$>$ To identify the existing scenario of climatic variables which is expedited to disaster extend

$>$ To assess the drought and flood hazard 
To evaluate the climatic change using moisture index

$>$ To assess the vulnerability of groundwater resulting from climatic impact

\subsection{Justification of the Study}

The natural and manmade disaster continuously affect to the northern part of Bangladesh. The vulnerable group cannot cope with risk at the time of forthcoming hazards, who are living below the poverty line. The developmental organization (Government and Non government organization) is attempted in several times to identify the main cause of massive disaster in this area. It is imperative demand to make ensure sustainability with facing against natural and manmade hazards for the future development. The skilled knowledge and support will be act as key factor to expedite the potential research activities which is important to make acceptance to achieve development goals in the study area.

\subsection{Location of the study area}

\section{Methodology}

The study area is located between 26.043 latitude and 88.4554 longitudes respectively. Establishment of Rangpur City Corporation, as Divisional City is now under way after the establishment of Rangpur Division in January 2010. The area of Rangpur City Corporation is estimated to be around 100 square kilometer accommodating about 6 million population by Census of 2011. Rangpur city would be the fifth largest city of Bangladesh after Dhaka (125 million), Chittagong (30 million), Khulna (10 million) and Rajshahi (8 million) estimated population by the 2011 census.

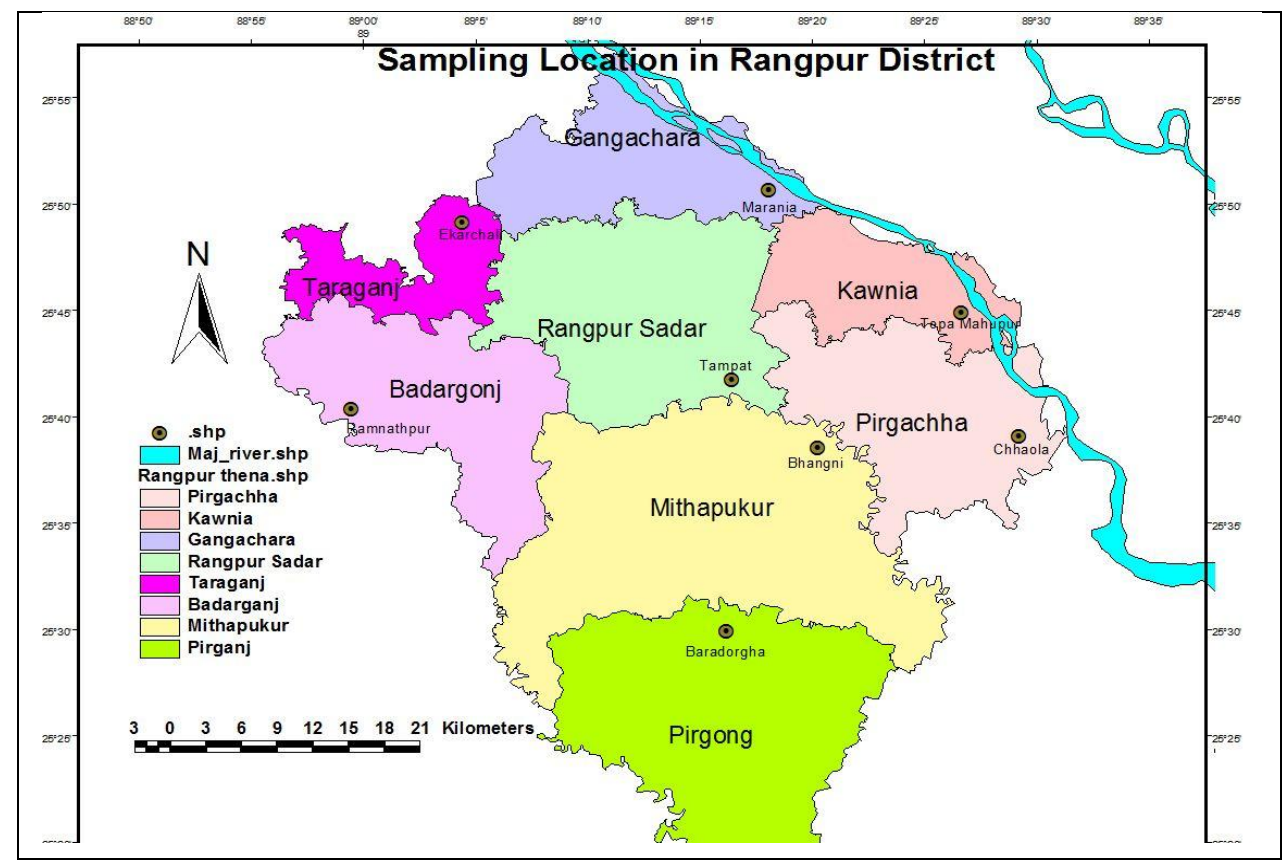

Figure1: Study Area

\subsection{Data Collection}

The project has been done through primary and secondary data collection. The primary data has been collected by the structural questionnaire survey. Secondary data has been collected from Bangladesh water development board (BWDB), Bangladesh Meteorological department (BMD) and Barind Multipurpose Development Authority (BMDA).The geographical information system (GIS) would be applied to prepare a location map, sampling point, spatial distribution analysis and find out the vulnerable region by using GIS.

\subsection{Statistical Analysis}

The statistical analysis will be performed using SSPSS (version 18.0), Sigmaplot (Version 9) package for windows. The statistical analysis will be emphasized on thematic model calculation (Fitting curve, Fitting of Straight Line by Least Square Method and ARMA auto regressive moving average ) for the better understanding 
about drought vulnerability, projection of climatic variable (rainfall, temperature and groundwater level data) followed by Gupta and Kapoor (2005).

\subsection{Mathematical Model}

\subsubsection{Hazard index calculation}

Shahid and Behrawan (2008) calculated drought hazard index (DHI) by the following formula:

$\mathrm{DHI}=(\mathrm{MDr} \times \mathrm{MDw})+(\mathrm{SDr} \times \mathrm{SDw})+(\mathrm{VSDr} \times \mathrm{VSDw})$

where, MDr, ratings assigned to moderate droughts occurrence classes; MDw, weight given to the theme of moderate drought occurrence theme; SDr, ratings assigned to severe droughts occurrence classes; SDw, weight given to the theme of severe drought occurrence theme; VSDr, ratings assigned to very severe droughts occurrence classes; VSDw, weight given to the theme of very severe drought occurrence theme.

In the present study annual occurrence is calculated by the following formula (Ragunath, 1995). The annual occurrences of droughts and floods are computed by the formula:

Annual occurrence $\mathrm{P}_{\mathrm{a}}=\mathrm{m} / \mathrm{y}$

Where, $\mathrm{m}=$ number of years during a time period, $\mathrm{y}=$ time period

The percentage of annual occurrence of droughts and floods is calculated as annual occurrence multiplying by 100 .

Shahid and Behrawan (2008) did not assign weight for normal drought. They assigned rating for different drought based on the percentage of occurrence and are given in Table 1.

Table 1: Weights and ratings assigned to drought severity themes and features of the themes, respectively (Shahid and Behrawan, 2008)

\begin{tabular}{|c|c|c|c|}
\hline Drought Severity & Weight & Percentage of occurrences & Rating \\
\hline \multirow[t]{4}{*}{ Moderate } & \multirow[t]{4}{*}{1} & $\leq 9.0$ & 1 \\
\hline & & $9.1-10$ & 2 \\
\hline & & $10.1-11$ & 3 \\
\hline & & $\geq 11.1$ & 4 \\
\hline \multirow[t]{4}{*}{ Severe } & \multirow[t]{4}{*}{2} & $\leq 3.5$ & 1 \\
\hline & & $3.5-4.5$ & 2 \\
\hline & & $4.6-5.5$ & 3 \\
\hline & & $\geq 5.6$ & 4 \\
\hline \multirow[t]{4}{*}{ Very Sever } & \multirow[t]{4}{*}{3} & $\leq 1.5$ & 1 \\
\hline & & $1.6-2.0$ & \\
\hline & & $2.1-2.5$ & 3 \\
\hline & & $\geq 2.6$ & 4 \\
\hline
\end{tabular}

In the present study, the severity of droughts and floods are classified as normal, moderate, severe and extreme. Very sever drought term is considered as extreme drought and drought hazard index is calculated as

$\mathrm{DHI}=(\mathrm{MDr} \times \mathrm{MDw})+(\mathrm{SDr} \times \mathrm{SDw})+(\mathrm{EDr} \times \mathrm{EDw})$

Where, MDr, ratings assigned to moderate droughts occurrence classes; MDw, weight given to the theme of moderate drought occurrence theme; SDr, ratings assigned to severe droughts occurrence classes; SDw, weight given to the theme of severe drought occurrence theme; EDr, ratings assigned to extreme droughts occurrence classes; EDw, weight given to the theme of extreme occurrence theme.

In the present study also the flood hazard index (FHI) is calculated as like as drought hazard index and the formula is given as:

$\mathrm{FHI}=(\mathrm{MFr} \times \mathrm{MFw})+(\mathrm{SFr} \times \mathrm{SFw})+(\mathrm{EFr} \times \mathrm{EFw})$

Where, MFr, ratings assigned to moderate flood occurrence classes; MFw, weight given to the theme of moderate flood occurrence theme; SFr, ratings assigned to severe flood occurrence classes; SFw, weight given to the theme of severe flood occurrence theme; EFr, ratings assigned to extreme flood occurrence classes; EDw, weight given to the theme of extreme flood occurrence theme.

\subsubsection{Risk ranking frequency calculation and adaptation}

The return period is the mean time that elapses between occurrence of an event of a given size; for example, total rainfall at a location exceeding or matching a certain amount (Nzewi, 2001).

$P(x \geq X)=\frac{1}{T}=P(X)$

Where $\mathrm{T}$ is return period (year)

DOI: $10.9790 / 2402-101001105114$

www.iosrjournals.org

107 | Page 
$P(x<X)=1-P(x \geq X)=P(\bar{X})$

$=1-\frac{1}{T}$

2.4.3 Return period or Frequency $T$

$T=\frac{1}{1-P(x \leq X)}=\frac{1}{1-[1-P(x \leq X)]}$

The criteria for categorizing frequency include the following options (Ramamasy and Bass, 2007):

High frequency - events that occur more frequently than once in three years;

Moderate frequency - events that occur from once in three years to five years;

Low frequency - events that occur from once in five years to once in ten years;

Very low frequency - events that occur less than once in ten years

One can also define their own frequency category based on the nature and severity of risks. Both the magnitude and frequency of a climate event are given qualitative measures that permit the prioritization of selected climate risks among multiple risks. Because the low frequency events may become high frequency events under climate change, they need to be given sufficient consideration (Ramamasy and Bass, 2007).

Class A: High-risk condition with highest priority for implementing adaptation measures;

Class B: Moderate-to-high risk condition with risk to be addressed by adaptation;

Class C: Risk condition sufficiently high to give consideration for further adaptation initiatives; and

Class D: Low-risk condition with additional adaptation initiatives.

Risk ranking figure of Ramamasy and Bass in 2007 is shown in figure 2.

\begin{tabular}{|c|c|c|c|c|}
\hline High & $\mathrm{C}$ & B & $\mathrm{A}$ & $\mathrm{A}$ \\
\hline Moderate & $\mathrm{C}$ & $\mathrm{B}$ & B & $\mathrm{A}$ \\
\hline low & $\mathrm{D}$ & $\mathrm{C}$ & B & B \\
\hline Very Low & $\mathrm{D}$ & $\mathrm{D}$ & $\mathrm{C}$ & $\mathrm{C}$ \\
\hline & Minor & Serious & Extensive & Catastrophe \\
\hline
\end{tabular}

Figure 2: Risk ranking figure

\subsection{Methods to Evaluate Climatic Change}

The climatic change has been evaluated using the potential evapotranspiration and moisture index calculation of twenty years interval from 1970 to 2010. The province was detected with the changing moisture index and compared the change between 1970-1990 and 1970-2010.

\subsubsection{Potential Evapotranspiration and Moisture Index Calculation}

Potential Evapotranspiration (PE) can be calculated followed by Thornthwaite (1948) model:

$\mathrm{PE}($ in $\mathrm{cm})=1.6\left(\frac{10 t}{I}\right)^{a}---------(9)$

Where, $\mathrm{I}=$ the sum of 12 months of $\left(\frac{t}{5}\right)^{1.514}$ and

$\mathrm{a}=\mathrm{a}$ further complex function of $\mathrm{I}$.

$=\left(0.675 \mathrm{I}^{3}-77.1 \mathrm{I}^{2}+17920 \mathrm{I}+492390\right) * 10^{-6}$

The monthly water surplus (S) or deficit (D) can calculated from a moisture budget assessment including soil moisture. A moisture index $\left(\mathrm{I}_{\mathrm{m}}\right)$ can be given by the following formula: 
$\mathrm{I}_{\mathrm{m}}=\left(\frac{100 S-60 D}{P E}\right)----------(10)$

The most characteristic feature of this classification scheme is that the temperature efficiency is calculated from the PE value, this being a function of temperature. Using computed indices moisture and heat, thornthwaite define the moisture and thermal provinces as Table 2.

Table 2: Moisture Index $\left(\mathrm{I}_{\mathrm{m}}\right)$ and Humidity Province

\begin{tabular}{|l|l|l|}
\hline Sl No & $\mathrm{I}_{\mathrm{m}}$ & Humidity Province \\
\hline 1 & 100 and above & A Tropical \\
\hline 2 & 80 to 100 & $\mathrm{~B}_{4}$ Humid \\
\hline 3 & 60 to 80 & $\mathrm{~B}_{3}$ Humid \\
\hline 4 & 40 to 60 & $\mathrm{~B}_{2}$ Humid \\
\hline 5 & 20 to 40 & $\mathrm{~B}_{1}$ Humid \\
\hline 6 & 0 to 20 & $\mathrm{C}_{2}$ Moist and humid \\
\hline 7 & -33.3 to 0 & $\mathrm{C}_{1}$ Dry sub humid \\
\hline 8 & -66.7 to -33.3 & D semi humid \\
\hline 9 & -100 to -66.7 & E Arid \\
\hline
\end{tabular}

\subsection{Methods to Assessing the Vulnerability of Groundwater Using Drastic Model}

\subsubsection{Description of the DRASTIC method}

Several aquifer vulnerability mapping methods have been developed by different researchers since 1970 . However, DRASTIC has been the most commonly used for mapping aquifer vulnerability in porous aquifers (Aller et al., 1987). In this study, the DRASTIC method was selected for determination of aquifer vulnerability in the basin because the main contamination sources are mine leaching to groundwater and intersection of aquifer by top soil removing due to open pit mining.

A DRASTIC method was derived from ratings and weights associated with the seven parameters. These are depth to groundwater (D), net recharge (R), and aquifer media (A), soil media (S), topography (T), influence of the vadose zone (I) and hydraulic conductivity (C). Each parameter is subdivided into ranges and is assigned different ratings in a scale of 1 (least contamination potential) to 10 (highest contamination potential) based on functional curves (Table 3). This rating is scaled by a groundwater contamination due to coal mining activities and DRASTIC weighting factors ranging between 1 (least significant) and 5 (most significant). In this study, contamination weight was used for alluvium areas and DRASTIC weight was used for the other areas of the basin. The linear additive combination of the above parameters with the ratings and weights was used to calculate the DRASTIC Vulnerability Index (DVI) as given below (Aller et al., 1987):

$D V I=D_{r} D_{w}+R_{r} R_{w}+A_{r} A_{w}+S_{r} S_{w}+T_{r} T_{w}+I_{r} I_{w}+C_{r} C_{w}$

Where,

$\mathrm{D}_{\mathrm{r}} \quad$ Rating for the depth to water table

$\mathrm{D}_{\mathrm{w}} \quad$ Weight assigned to the depth to water table

$\mathrm{R}_{\mathrm{r}} \quad$ Rating for aquifer recharge

$\mathrm{R}_{\mathrm{w}} \quad$ Weight for aquifer recharge

$\mathrm{A}_{\mathrm{r}} \quad$ Rating assigned to aquifer media

$\mathrm{A}_{\mathrm{w}} \quad$ Weight assigned to aquifer media

$\mathrm{S}_{\mathrm{r}} \quad$ Rating for the soil media

$\mathrm{S}_{\mathrm{w}} \quad$ Weight for the soil media

$\mathrm{T}_{\mathrm{r}} \quad$ Rating for topography (slope)

$\mathrm{T}_{\mathrm{w}} \quad$ Weight assigned to topography

$\mathrm{I}_{\mathrm{r}} \quad$ Rating assigned to impact of vadose zone

$\mathrm{I}_{\mathrm{w}} \quad$ Weight assigned to impact of vadose zone

$\mathrm{C}_{\mathrm{r}} \quad$ Rating for rates of hydraulic conductivity

$\mathrm{C}_{\mathrm{w}} \quad$ Weight given to hydraulic conductivity

The rating ranges were determined depending on the properties of the study area only. The range component divides each DRASTIC parameter into several classes, or significant media types that may affect the potential for 
pollution (Ehteshami et al., 1991). This rating range may change from one study area to another. Good knowledge of the geology and hydrogeology of the research area is a prerequisite to determine rating ranges of the parameters.

\subsubsection{The proposed modified DRASTIC-DHI-FHI model}

The modified DRASTIC model was done followed by Sener and Davraz (2013). The DVI was calculated using new rating and weight values for each of the nine parameters using the modified DRASTIC-DHI-FHI method with GIS techniques mentioned previously. The weights of specific criteria are established by ranking their importance and suitability (Sener et al., 2009). Modifying the DRASTIC model to accommodate local hydrological settings and combining the use of GIS made it possible to create a visual tool representing areas of risk (Klug, 2009). By adding two parameters draught hazard index (DHI) and flood hazard index (FHI) with DRASTIC model a new name has been proposed such as Modified DRASTIC-DHI-FHI.

The DRASTIC method was developed using 4 assumptions (Al-Zabet, 2002);

1. The pollutant is introduced at the ground surface

2. The pollutant is flushed into the groundwater by rainfall

3. The pollutant has the velocity of water

4. The area evaluated using DRASTIC is 40 hectares or larger.

Table 3: Rating and weighting values used in the modified DRASTIC-DHI-FHI methods

\begin{tabular}{|c|c|c|c|c|}
\hline \multirow[t]{2}{*}{ Parameters } & \multicolumn{4}{|c|}{ Modified DRASTIC-DHI-FHI } \\
\hline & Range & Rating & Weight & Total weight \\
\hline \multirow[t]{6}{*}{ Groundwater depth (m) D } & $0-1.5$ & 10 & \multirow[t]{6}{*}{5} & 50 \\
\hline & $1.5-3$ & 9 & & 45 \\
\hline & $3-5$ & 8 & & 40 \\
\hline & $5-7$ & 7 & & 35 \\
\hline & $7-10$ & 6 & & 30 \\
\hline & $10-20$ & 5 & & 25 \\
\hline \multirow[t]{7}{*}{ Net Recharge (mm/year) R } & $450-550$ & 3 & \multirow[t]{7}{*}{4} & 12 \\
\hline & $550-625$ & 5 & & 20 \\
\hline & $625-650$ & 6 & & 24 \\
\hline & $650-675$ & 7 & & 28 \\
\hline & $675-700$ & 8 & & 32 \\
\hline & $700-725$ & 9 & & 36 \\
\hline & $725-750$ & 10 & & 40 \\
\hline \multirow[t]{3}{*}{ Aquifer media $\mathrm{A}$} & Alluvium & 4 & \multirow[t]{3}{*}{3} & 12 \\
\hline & Sandy braided river & 5 & & 15 \\
\hline & Sand & 9 & & 27 \\
\hline \multirow[t]{4}{*}{ Soil media S } & Gravel & 9 & \multirow[t]{4}{*}{2} & 18 \\
\hline & Sedimentation & 8 & & 16 \\
\hline & Sand-clay & 3 & & 6 \\
\hline & Clay & 1 & & 2 \\
\hline \multirow[t]{5}{*}{ Topograpgy $\left(\right.$ slope $\left.^{0}\right) \mathrm{T}$} & $0-2$ & 10 & \multirow[t]{5}{*}{1} & 10 \\
\hline & $2-6$ & 9 & & 9 \\
\hline & $6-12$ & 5 & & 5 \\
\hline & $12-20$ & 3 & & 3 \\
\hline & $20-32$ & 1 & & 1 \\
\hline \multirow[t]{3}{*}{ Impact of vadose zone I } & Gravel & 9 & \multirow[t]{3}{*}{5} & 45 \\
\hline & Silt & 3 & & 15 \\
\hline & Clay & 1 & & 5 \\
\hline \multirow[t]{3}{*}{ Hydraulic conductivity $(\mathrm{m} / \mathrm{s}) \mathrm{C}$} & $3 \times 10^{-4}-3 \times 10^{-2}$ & 10 & \multirow[t]{3}{*}{3} & 30 \\
\hline & $10^{-9}-2 \times 10^{-5}$ & 3 & & 9 \\
\hline & $10^{-11}-4.7 \times 10^{-9}$ & 1 & & 3 \\
\hline \multirow[t]{4}{*}{ Drought Hazard Index (DHI) } & Normal & 1 & \multirow[t]{4}{*}{5} & 5 \\
\hline & Moderate & 3 & & 15 \\
\hline & Severe & 6 & & 30 \\
\hline & Extreme & 9 & & 45 \\
\hline \multirow[t]{4}{*}{ Flood Hazard Index (FHI) } & Normal & 1 & \multirow[t]{4}{*}{5} & 5 \\
\hline & Moderate & 3 & & 15 \\
\hline & Severe & 6 & & 30 \\
\hline & Extreme & 9 & & 45 \\
\hline
\end{tabular}

(Data source: BWDB, 2005 and BMD, 2014 and, 2014) 
A database was established in order to input the collected data into Arcview 3.3 GIS, which offers the ability to store, manipulate and analyse data in different formats and at different scales (Rahman, 2008; Sener et al., 2009). Once in the database, it is then possible to register all data as data layers with a common coordinate system and manipulate them to produce thematic maps, including the overall study area vulnerability map.

\subsection{Hydrometeorological Hazards}

\section{Result And Discussions}

Hydro meteorological hazards like rainfall flood and meteorological drought have been identified and classified on the basis of four thresholds. Long term mean rainfall of Rangpur is almost $2170 \mathrm{~mm}$ which is $130 \mathrm{~mm}$ lower than the mean rainfall of Bangladesh. Deviation of annual rainfall from long term mean rainfall is calculated in percentage and also the annual rainfall in mm and 3 years moving average is reflected in fig 2.

The median year between 1954 and 2010 is 1982 . From fig 2, it is clear that the number of rainfall flood years is increasing after the median year. A total of 8 rainfall flood events have been identified from 1954 to 1981 , and 20 years in the period the area affected by meteorological drought. To understand the severity of flood and drought the rainfall deviation from mean in percentage is given in Table 4 and 5.

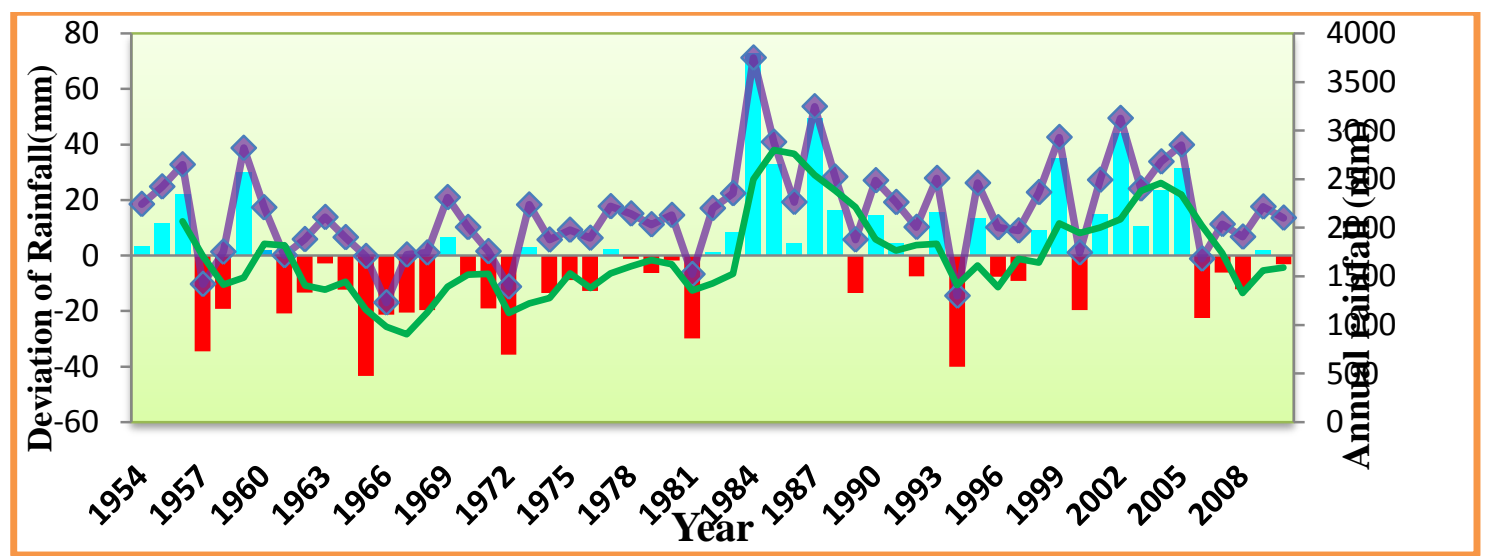

Figure 3: Primary axis reflects deviation of rainfall with respect to long term mean.

The Aqua color above axis (positive deviation from mean) indicates rainfall flood and red color below axis (negative deviation from mean) indicates meteorological drought. The secondary axis indicates (Purple color) annual rainfall $(\mathrm{mm})$ and green color represent 3 years moving average trend of Rangpur

Table 4: Different types of rainfall flood of Rangpur between 1954 and 2010

\begin{tabular}{|c|c|c|c|c|c|c|c|}
\hline \multicolumn{2}{|c|}{ Normal flood } & \multicolumn{2}{|c|}{ Moderate flood } & \multicolumn{2}{|c|}{ Severe flood } & \multicolumn{2}{|c|}{ Extreme flood } \\
\hline Year & $\begin{array}{l}\text { Deviation of } \\
\text { rainfall }(\%)\end{array}$ & Year & $\begin{array}{l}\text { Deviation of } \\
\text { rainfall }(\%)\end{array}$ & Year & $\begin{array}{l}\text { Deviation of } \\
\text { rainfall (\%) }\end{array}$ & Year & $\begin{array}{l}\text { Deviation of } \\
\text { rainfall }(\%)\end{array}$ \\
\hline 1954 & 3.4 & 1955 & 11.7 & 1956 & 22.12 & 1959 & 30.0 \\
\hline 1960 & 1.8 & 1988 & 16.3 & 2004 & 23.5 & 1984 & 72.7 \\
\hline 1969 & 6.6 & 1990 & 14.6 & & & 1985 & 32.8 \\
\hline 1973 & 3.1 & 1993 & 15.7 & & & 1987 & 49.6 \\
\hline 1977 & 2.3 & 1995 & 13.4 & & & 1999 & 35.1 \\
\hline 1982 & 1.4 & 2001 & 14.8 & & & 2002 & 44.1 \\
\hline 1983 & 8.5 & 2003 & 10.7 & & & 2005 & 31.5 \\
\hline 1986 & 4.3 & & & & & & \\
\hline 1991 & 4.3 & & & & & & \\
\hline 1998 & 9.0 & & & & & & \\
\hline 2009 & 2.2 & & & & & & \\
\hline
\end{tabular}


Evaluation of Climate Change Impact And Groundwater Vulnerability Assessment In Rangpur District, ..

Table 5: Different types of meteorological drought of Rangpur between 1954 and 2010

\begin{tabular}{|c|c|c|c|c|c|c|c|}
\hline \multicolumn{2}{|c|}{ Normal drought } & \multicolumn{2}{|c|}{ Moderate drought } & \multicolumn{2}{|c|}{ Severe drought } & \multicolumn{2}{|c|}{ Extreme drought } \\
\hline Year & $\begin{array}{l}\text { Deviation } \\
\text { rainfall }(\%)\end{array}$ & Year & $\begin{array}{l}\text { Deviation } \\
\text { rainfall }(\%)\end{array}$ & Year & $\begin{array}{l}\text { Deviation } \\
\text { rainfall }(\%)\end{array}$ & Year & $\begin{array}{l}\text { Deviation } \\
\text { rainfall }(\%)\end{array}$ \\
\hline 1963 & -2.8 & 1958 & -19.2 & 1961 & -20.9 & 1957 & -34.5 \\
\hline 1970 & -7.6 & 1962 & -13.3 & 1965 & -21.3 & 1966 & -43.3 \\
\hline 1975 & -8.8 & 1964 & -12.4 & 1967 & -20.6 & 1972 & -35.8 \\
\hline 1978 & -1.2 & 1968 & -19.6 & 1981 & -29.8 & 1994 & -40.0 \\
\hline 1979 & -6.3 & 1971 & -19.0 & 2006 & -22.5 & & \\
\hline 1980 & -1.8 & 1974 & -13.5 & & & & \\
\hline 1992 & -7.5 & 1976 & -12.7 & & & & \\
\hline 1996 & -7.6 & 1989 & -13.5 & & & & \\
\hline 1997 & -9.2 & 2000 & -19.6 & & & & \\
\hline 2007 & -6.1 & 2008 & -12.1 & & & & \\
\hline 2010 & -3.1 & & & & & & \\
\hline
\end{tabular}

A total of 6 meteorological drought events have been identified as normal drought (negative deviation of rainfall from mean 1 to 9.9) years from 1954 to 1981 . Moreover 8 moderate (negative deviation of rainfall from 10 to 19.9), 4 severe (negative deviation of rainfall from 20 to 29.9) and 3 (negative deviation of rainfall above 29.9) extreme drought years have been identified before the median year. On the other hand 5 normal floods (positive deviation of rainfall from mean to 9.9), 1 moderate (positive deviation of rainfall from 10 to 19.9), 1 severe (positive deviation of rainfall from 20 to 29.9) and 1 extreme (positive deviation of rainfall from 30 to above 30) have been identified. Three year moving average trend is to detect any year rainfall greater or less than this time length. The extreme flood years receive more rainfall than this time length and extreme drought year's less rainfall than this time length (Figure 2). However after the median year, a total number of 18 rainfall flood events have been identified from 1983 to 2010, and 11 years in the period the area affected by meteorological drought (Figure 2 and Table 3 and 4). A total of six extreme rainfall floods have been identified from 1954 to 2010 . All these extreme rainfall floods happened after the median year. The highest deviation of rainfall between 1954 and 2010 is +72.2\% (1984). The second highest deviation of rainfall is $+49.6 \%$ in 1987. Moreover in the years 1985, 1999, 2002 and 2005 the deviations of rainfall from mean are $+32.8,+35.1,+44.1$ and +31.5 respectively, which indicate extreme rainfall flood. On the contrary, only one extreme drought event has been identified after the median year that happened in 1994 and the rainfall deviation was $-40 \%$. The most persistent drought in recent times caused immense crop damage especially rice and jute the main crops of northwest Bangladesh. Moreover normal rainfall drought affected in the areas 1992, 1996, 1997, 2007 and 2010 and rainfall deviation were -7.5, -7.6, -9.2, -6.1 and -3.1. Moderate and severe droughts also affected in the years 2008, 2000 and 2006 when the rainfall deviations were -12.1, -19.6 and 22.5 respectively.

\subsection{Potential Evapotranspiration and Moisture Index Calculation}

Potentialevapotranspiration (PE) and moisture index $\left(\mathrm{I}_{\mathrm{m}}\right)$ was calculated for three times. First spell twelve years from 1970 to1991, second spell thirty one years from 1970 to 2000 and third spell forty one years from 1970 to 2010 Table 6 . The moisture index $\left(\mathrm{I}_{\mathrm{m}}\right)$ has been decreased from $1^{\text {st }}$ spell to $2^{\text {nd }}$ spell but in third spell the moisture index has been drastically decreased and it is from -12.08 to -37.89 . Also moisture index has been calculated for last twenty years (1991-2010) Table 7 and found that moisture index has been found -71.74.

Table 6: Potentialevapotranspiration and moisture index calculation of 1970-91, 1970-2000 and 1970- 2010.

\begin{tabular}{|c|c|c|c|c|c|c|c|c|c|}
\hline \multirow[t]{2}{*}{ Month } & \multirow[t]{2}{*}{ 1970-91 } & \multirow[t]{2}{*}{$1970-2000$} & \multirow[t]{2}{*}{ 1970-2010 } & \multicolumn{3}{|l|}{ PE } & \multicolumn{3}{|l|}{ Im } \\
\hline & & & & $1970-91$ & $1970-2000$ & $1970-2010$ & $1970-91$ & 1970-2000 & 1970-2010 \\
\hline January & 16.90 & 16.65 & 15.33 & 3.93 & 3.77 & 3.00 & -32.55 & -33.94 & -42.63 \\
\hline February & 18.58 & 18.74 & 17.63 & 5.10 & 5.22 & 4.41 & -148.68 & -145.21 & -171.95 \\
\hline March & 22.29 & 22.65 & 21.56 & 8.42 & 8.80 & 7.68 & -68.59 & -65.62 & -75.20 \\
\hline April & 24.79 & 25.29 & 24.41 & 11.30 & 11.94 & 10.83 & -9.72 & -9.20 & -10.14 \\
\hline May & 25.26 & 25.97 & 25.36 & 11.90 & 12.84 & 12.03 & -8.98 & -8.32 & -8.88 \\
\hline June & 26.77 & 27.29 & 26.75 & 13.96 & 14.73 & 13.94 & 34.23 & 32.46 & 34.28 \\
\hline July & 26.88 & 27.46 & 27.13 & 14.12 & 14.98 & 14.50 & 45.10 & 42.52 & 43.94 \\
\hline August & 27.41 & 27.84 & 27.49 & 14.91 & 15.56 & 15.02 & 46.83 & 44.86 & 46.46 \\
\hline September & 26.51 & 26.97 & 26.63 & 13.59 & 14.25 & 13.77 & 25.53 & 24.34 & 25.20 \\
\hline October & 25.05 & 25.45 & 24.83 & 11.63 & 12.15 & 11.35 & 27.27 & 26.10 & 27.94 \\
\hline November & 21.94 & 22.08 & 21.08 & 8.06 & 8.21 & 7.22 & 6.08 & 5.97 & 6.79 \\
\hline December & 18.45 & 18.37 & 17.23 & 5.00 & 4.94 & 4.14 & 71.42 & 72.28 & 86.29 \\
\hline Sum of I & 125.30 & 128.09 & 122.11 & Sum of I & & & -12.08 & -13.76 & -37.89 \\
\hline
\end{tabular}


Compare this calculated value Table 7 with the indexing value Table 2. It Has been found that in 1970 1990 this region has been found as a $\mathrm{C}_{1}$ dry sub humid province but in 1991-2010 this region has been recognized as a $\mathrm{E}$ arid province.

Table 7: Moisture Index $\left(\mathrm{I}_{\mathrm{m}}\right)$ Calculation

\begin{tabular}{|l|l|l|l|}
\hline $\mathbf{1 9 7 0 - 9 0}$ & $\mathbf{1 9 7 0 - 2 0 0 0}$ & $\mathbf{1 9 7 0 - 2 0 1 0}$ & $\mathbf{1 9 9 1 - 2 0 1 0}$ \\
\hline-32.55 & -33.94 & -42.63 & -58.2548 \\
\hline-148.68 & -145.21 & -171.95 & -202.249 \\
\hline-68.59 & -65.62 & -75.20 & -83.133 \\
\hline-9.72 & -9.20 & -10.14 & -10.6168 \\
\hline-8.98 & -8.32 & -8.88 & -8.78367 \\
\hline 34.23 & 32.46 & 34.28 & 34.33496 \\
\hline 45.10 & 42.52 & 43.94 & 42.77815 \\
\hline 46.83 & 44.86 & 46.46 & 46.08123 \\
\hline 25.53 & 24.34 & 25.20 & 24.84815 \\
\hline 27.27 & 26.10 & 27.94 & 28.66504 \\
\hline 6.08 & 5.97 & 6.79 & 7.664467 \\
\hline 71.42 & 72.28 & 86.29 & 106.9239 \\
\hline$\square \mathbf{I}_{\mathbf{m}=\mathbf{- 1 2 . 0 8}}$ & $\square \mathbf{I}_{\mathbf{n}}=\mathbf{- 1 3 . 7 6}$ & $\square \mathbf{I}_{\mathbf{m}}=\mathbf{- 3 7 . 8 9}$ & $\square \mathbf{I}_{\mathbf{m}}=\mathbf{- 7 1 . 7 4}$ \\
\hline
\end{tabular}

\subsection{Groundwater vulnerability assessment using Modified DRASTIC-DHI-FHI Model}

In this study, the DRASTIC method was used for evaluation of groundwater vulnerability in Rangpur district. However, despite its success in some case studies, the DRASTIC method has some disadvantages. The influence of regional characteristics (geology, hydrology, hydrogeology, contamination index etc.) is not accounted for in the method and so the same weights and rating values are used everywhere. If the detailed hydro-geological properties such as aquifer type, aquifer thickness, groundwater level and groundwater flow direction etc., are well known, more reliable results can be obtained with this method. In order to better address local issues for refined representation of local hydro-geologic settings, researchers envisaged several modifications of the original DRASTIC model.

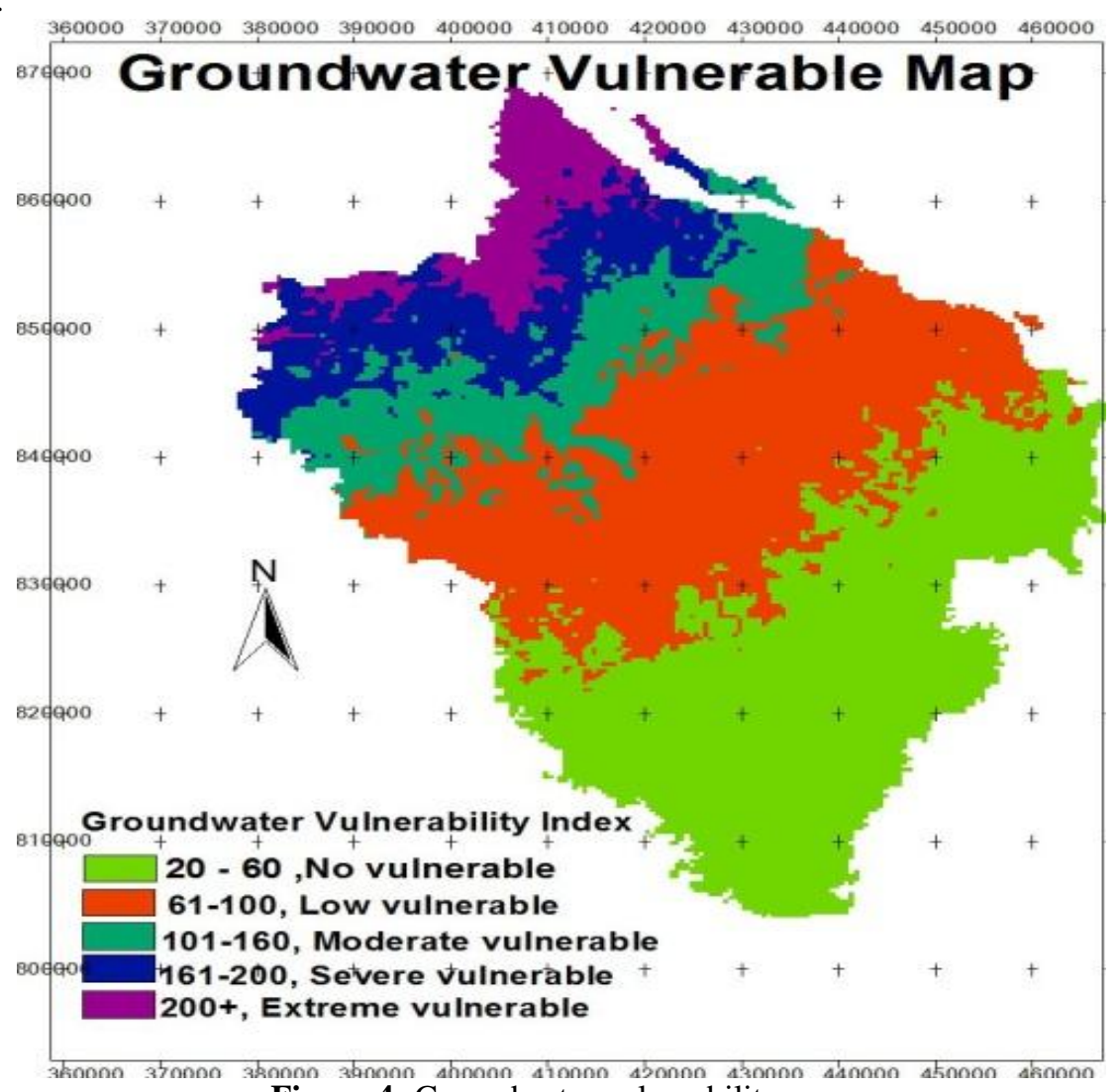

Figure 4: Groundwater vulnerability map 
Evaluation of Climate Change Impact And Groundwater Vulnerability Assessment In Rangpur District, ..

The modifications were in the form of additional parameters, removal of certain parameters and usage of different ratings and weights for the parameters. The calculated DVI value for the modified- DRASTIC-DHI-FHI map was found more than one third area become moderate to extreme vulnerable. From the using of DRASTIC method the study area will be highly contaminated. The accuracy of weights and rating values of the DRASTIC parameters is important for validity of this method. The DRASTIC method is rigid in the assignment of ratings and weights to the model parameters. In this study, detailed hydro-geological field studies were performed to reduce the margin of error. The rating values of the parameters were determined, dependent on field and regional properties of the study area.

\section{Conclusion}

Groundwater vulnerability assessment was carried out in Rangpur district due to climate change and with an aim to assess the climatic change evaluation and groundwater vulnerability. The climatic parameter such as rainfall and temperature were used to evaluate the changes of climate. Moisture index, drought hazard index, flood hazard index and groundwater vulnerability assessment were calculated following the Thornthwaite model (1948), Shahid and Behrawan (2008) and GIS based DRASTIC model. The analysis reveals that amount of rainfall increases at $6.92-13.45 \mathrm{~mm} / \mathrm{year}$ with a rate of $6.43-7.24 \%$ of mean annual rainfall from 2000 to 2010 . The mean summer rainfalls of recent eleven years mean (2000-10) went up by 24-30\% than that of base line average with the highest percentage may increase during the summer season. Annual mean temperature changes $+0.02172^{\circ} \mathrm{C} /$ year at Rangpur where annual average mean temperature of recent eleven years mean (2000-2010) has already increased $0.6^{\circ} \mathrm{C}$. Risk ranking revel that severity and frequency rainfall flood is higher than meteorological drought and the highest flood risk indicate moderate-to-high flood risk condition. The highest meteorological drought risk indicates drought risk condition sufficiently high. Moisture index become very low than that of previous year. It was found the moisture index has been drastically decreased and it decreases from -12.08 to -37.89 . Also moisture index has been calculated for last twenty years (1991-2010) Table 7 and found that moisture index has been found -71.74 . Compare this calculated value (Table 7) with the indexing value Table 2. It has been found that in $1970-1990$ this region was found as a $C_{1}$ dry sub humid province but in 1991-2010 this region has been recognized as a $E$ arid province. Groundwater level is declining at an alarming rate which causing the groundwater moderate vulnerable to high vulnerable condition.

\section{References}

[1]. ADB. 1994. Climate Change in Asia: Bangladesh Country Report. Regional Study on Global Environmental issues. Asian Development Bank. Regional Study on Global Environmental Issues Series, Manila, Philippines.

[2]. Aller, L., Bennet, T., Lehr, J. H., Petty, R. J. and Hackett, G. (1987) DRASTIC: A Standardized System for Evaluating Groundwater Pollution Potential using Hydrogeological Settings. EPA/600/2-87/035. US Environmental Protection Agency, Ada, OK, USA.

[3]. Al-Rawabdeh, A. M., Nadhir A., Al-Ansari, Ahmed A., Al-Taani and Knutsson S. (2013) A GIS-Based Drastic Model for Assessing Aquifer Vulnerability in Amman-Zerqa Groundwater Basin, Jordan. Scientific Research. http://dx.doi.org/10.4236/eng.2013.55059. [Accessed: 6 April, 2010].

[4]. Al-Zabet, T. (2002) Evaluation of aquifer vulnerability to contamination potential using the DRASTIC method. Environmental Geology. 43: pp. 203-208.

[5]. Banglapedia 2003. National encyclopedia of Bangladesh. Asiatic Society of Bangladesh, Dhaka

[6]. Edwards, K. J., Bond, P. L., Druschell, G. K., McGuire, M. M., Hamers, R. J. and Banfield, J. F. (2009) Geochemical and biological aspects of sulfide mineral dissolution: lessons from Iron Mountain, California. Chemical Geology. 169(3-4): pp. 383-397.

[7]. Ehteshami, M., Peralta, R. C., Eisele, H., Deer, H. and Tindall, T. (1991) Assessing pesticide contamination to ground water: a rapid approach. Ground Water. 29: pp. 862-868.

[8]. Gupta, S.C. and Kapoor, V.K. 2005. Fundamental of Applied Statistics, Sultan Chand and Sons, New Delhi, India.

[9]. IPCC. 2008. Climate change and Water. Intergovernmental Panel on Climate Change Technical Guide Lines Four.

[10]. Klug, J. (2009) Modeling the Risk of Groundwater Contamination Using DRASTIC and Geographic Information System in Houston Country, Minnesota. Volume 11, Papers in Resources Analysis. 12 pp. Saint Mary's University of Minnesota University Central Services Press. Winona, MN. Retrieved (date). http://www.gis.smumn.edu

[11]. Nzewi, E. U. (2001) Water Resources, McGraw-Hill Publisher, pp. 45-66. p.391-413.

[12]. Raghunath, H.M. 1995. Hydrology - Principles, Analysis, Design. New Age International Publisher.

[13]. Rahman, A. (2008) A GIS based DRASTIC model for assessing groundwater vulnerability in shallow aquifer in Aligarh, India. Appl Geogr. 28: pp. 32-53.

[14]. Ramamasy, S. and Baas, S. 2007. Climate variability and change: adaptation to drought in Bangladesh, A resource book and training guide, Rome.

[15]. Sener, E. and Davraz, A. (2013) Assessment of groundwater vulnerability based on a modified DRASTIC model, GIS and an analytic hierarchy process (AHP) method: the case of Egirdir Lake basin (Isparta, Turkey). Hydrology Journal.v. 21: pp.701-714.

[16]. Sener, E., Sener, S. and Davraz, A. (2009) Assessment of aquifer vulnerability based on GIS and DRASTIC methods: a case study of Senirkent- Uluborlu basin (Isparta, Turkey). Hydrogeol J 17: pp. 2023-2035.

[17]. Shahid, S. and Behrawan, H. 2008. Drought risk assessment in the western part of Bangladesh. Nat Hazards, v.46,

[18]. Thornthwaite, C.W. 1948. An approach toward a rational classification of climate. Geogr Rev, v.38, p.55-94. 